\title{
ANALISIS SEMIOTIK TERHADAP IKLAN SAMPOERNA A MILD HIJAU EDISI DATENG KONDANGAN
}

\author{
Sony Wicaksono, Mukaromah \\ Universitas Dian Nuswantoro \\ soni.ws.93@gmail.com
}

\begin{abstract}
Abstrak
Iklan adalah sarana komunikasi persuasif yang bertujuan mempengaruhi masyarakat untuk menggunakan jasa atau barang. Oleh karenanya, diperlukan sebuah iklan efektif untuk mampu meyakinkan dan mempersuasi khalayak. Peneliti memfokuskan pada iklan rokok Sampoerna A Mild Hijau karena merupakan salah satu produk yang terkenal dan terkemuka di Indonesia. Dalam iklan Sampoerna A Mild Hijau edisi Dateng Kondangan, terdapat beberapa simbol atau tanda yang disampaikan secara tersirat melalui teks, audio, maupun visual yang didalamnya sebenarnya melibatkan brand atau kompetitor lain. Tujuan dari penelitian ini adalah untuk melihat pemaknaan simbol-simbol iklan Sampoerna Hijau versi "Dateng Kondangan" dalam kajian semiotika. Penelitian ini menggunakan pendekatan kualitatif. Metode penelitian yang digunakan adalah metode analisis semiotik model Roland Barthes. Lewat model Roland Barthes, peneliti mampu mengungkap makna denotasi, konotasi, dan mitos. Penelitian ini menemukan data bahwa iklan tersebut menggambarkan persaingan produk rokok di Indonesia yang diwakili oleh brand kompetitor dimana asosiasi warna merah (Gudang Garam Merah), warna coklat (Djarum Coklat), dan hijau (Sampoerna Hijau).
\end{abstract}

Kata Kunci : Semiotika, Iklan Sampoerna, Iklan

\begin{abstract}
s
Advertising is the medium of persuasive communication that aims to influence people to use services or goods. Therefore, an effective advertisement is required to be able to convince and persuade audiences. The researcher focused on Sampoerna A Mild Green cigarette advertisement because it is one of the famous and leading products in Indonesia. There are brand competitor's symbols and signs that implicitly projected throughout the text, audio and visual contents. The aim of this research is to depict the symbols's meanings of this advertisement. This research uses qualitative approach. The research method used is semiotic analysis method of Roland Barthes model. Through the model Roland Barthes, researchers are able to uncover the meaning of denotation, connotation, and myth. This research finds the data that the advertisement describes competition of cigarette product in Indonesia represented by competitor brand where red color association (Gudang Garam Merah), brown color (Djarum Coklat), and green (Sampoerna Hijau).
\end{abstract}

Keywords: Semiotics, Sampoerna Advertisement, Advertisement 


\section{Pendahuluan}

Iklan adalah sarana komunikasi persuasif yang bertujuan untuk mempengaruhi dan membujuk masyarakat untuk menggunakan suatu produk, baik produk yang berupa jasa maupun barang. Iklan saat ini telah menjadi sarana bagi produsen yang memiliki anggaran besar untuk kegiatan promosi sebagai cara untuk mendongkrak penjualan produknya. Para creator iklan tentunya berusaha untuk membuat iklan semenarik mungkin untuk menyajikan atau menampilkan iklan yang agar dapat selalu diingat oleh masyarakat.Agar iklan dapat tersaji dengan menarik dan kreatif, pengiklan harus memahami khalayak mereka. Mereka harus mengakrabkan diri dengan cara berfikir konsumen, dengan faktor-faktor yang memotivasi hidup merela, serta lingkungan dimana mereka hidup (Lee \& Johson, 2004 : 108).

Aturan iklan rokok yang dibatasi secara ketat dan khusus dalam penayangannya, membuat indutsri rokok di Indonesia semakin tertantang untuk membuat iklan yang kreatif dan unik dengan mengoptimalkan unsur verbal maupun non verbalnya dalam kemasan audio visual yang di dalamnya terkandung banyak makna untuk mempersuasi masyarakat. Peraturan Pemerintah Republik Indonesia No.19 tahun 2003 tentang Pengamanan Rokok Bagi Kesehatan pasal 16 ayat 3 tentang jam tayang rokok di televisi hanya diperbolehkan pada pukul 21.30 05.00 waktu setempat, serta pasal 17 yang salah satu isinya berisi larangan menggambarkan bungkus rokok, rokok, serta kegiatan merokok baik melalui tulisan, gambar, maupun kombinasi keduanya (Peraturan Pemerintah No. 19 tahun 2003).

Aturan KPI pun juga memperketat penayangan iklan rokok yakni berdasarkan Standar Program Siaran (SPS) pasal 59 ayat 2, program siaran yang berisi segala bentuk dan strategi promosi yang dibuat oleh produsen rokok wajib dikategorikan sebagai iklan rokok.sehingga promosi film, event musik dan lain-lain yang dibiayai oleh industri rokok didefinisikan sebagai iklan rokok, yang wajib mematuhi ketentuan SPS tersebut.(Pedoman Perilaku Penyiaran dan Standar Program Siaran (P3SPS) Pasal 59 ayat 2).

Peneliti memfokuskan pada iklan rokok Sampoerna A Mild Hijau karena merupakan salah satu produk yang terkenal dan terkemuka di Indonesia. Berdasarkan Top Brand Award Kategori Rokok Mild 2008-2013, Sampoerna A Mild menjadi urutan pertama dalam Top Brand selama lima tahun berturut-turut (Topbrand-award.com). Perkembangan iklan Sampoerna A Mild khususnya Hijau mulai melambung tinggi dibenak masyarakat pada masa parade lima sekawan yang dikenal dengan nama Geng Hijau. Berdasarkan data dari Majalah SWA edisi 14/2005, 7 Juli 2005, Manager Merek PT HM Sampoerna Tbk. (HMS), Andi Darusman ingin lebih memaksimalkan potensi yang dimiliki Sampoerna Hijau di masa mendatang. Salah satunya dengan mencantumkan kata "Hijau" dalam kemasan barunya, yang sebelumnya tidak terdapat di kemasan lama.Merek Sampoerna Hijau terbentuk dengan sendirinya karena produk ini menggunakan kemasan yang berwarna hijau. Penambahan kata 'Hijau' dalam kemasan baru lebih ditujukan untuk memudahkan konsumen membedakan dari produk lain. Dengan penambahan kata 'Hijau' dalam kemasan, kini nama mereknya resmi menjadi Sampoerna Hijau. (Hidayat, Majalah SWA edisi 14/2005, 7 Juli 2005).

Penambahan kata "Hijau" dalam kemasan baru Sampoerna Hijau merupakan strategi 
yang sangat tepat. Manager tersebut menyebutkan, di kelas SKT (Sigaret Kretek Tangan) menengah, Sampoerna Hijau bersaing dengan pemain kuat lainnya, Gudang Garam Merah dan Djarum Coklat, yang juga menggunakan asosiasi warna. Yaitu warna "Merah" untuk merek Gudang Garam, dan warna "Coklat" untuk merek Djarum Coklat.“Kata 'Hijau' menjadi diferensiasi Sampoerna Hijau yang sangat jelas terhadap kompetitornya.Oleh karenanya, tidak heran apabila iklan-iklan Sampoerna Hijau pada saat ini difokuskan dengan asosiasi warna "Hijau" sebagai salah satu simbolik produk perusahaan PT HM Sampoerna Tbk. Hal inilah yang membuat peneliti tertarik untuk mengangkat iklan produk Sampoerna A Mild khususnya versi Hijau sebagai bahan kajian analisis. Selain itu, peneliti juga tertarik dengan iklan Sampoerna A Mild Hijau karena ditayangkan melalui konsep iklan yang sangat unik dan menarik. Produk ini juga memiliki positioning yang mengusung konsep "kebersamaan" sebagai kunci utamanya dalam beriklan (Kartajaya dkk, 2005 : 89).

Hal ini tampak dari setiap iklan Sampoerna A Mild Hijau mengangkat kisah yaitu tiga laki-laki yang senenatiasa bersama dalam melakukan kegiatan yang diusung dengan cerita yang humoris dan kreatif. Iklan Sampoerna A Mild Hijau versi "Dateng Kondangan" tersebut secara singkat bercerita mengenai tiga orang yang datang pada acara pernikahan dan mereka bingung untuk memilih makanan enak yang disajikan oleh tuan rumah. Mereka pun akhirnya mencoba satu per satu makanan, dari mulai yang warnanya cokelat (asosiasi Djarum Coklat) rasanya hambar, dan rasa tidak enak pada saat mencoba makanan yang berwarna merah (asosiasi Gudang Garam).

Dalam iklan tersebut terdapat beberapa simbol atau tanda yang disampaikan secara tersirat melalui teks, audio, maupun visual yang didalamnya sebenarnya melibatkan brand atau kompetitor lain. Untuk membedah iklan sebagai objek analisis, penulis menggunakan metode semiotika Roland Barthes. Barthes mengulas sistem pemaknaan yang dibangun atas sistem lain yang telah ada sebelumnya. Kedua sistem yang paling paling dikenal adalah sistem tataran denotatif dan sistem tataran konotatif.Dalam konsep Barthes, tanda konotatif tidak sekedar memiliki makna tambahan, namun juga mengandung kedua bagian tanda denotatif yang melandasi keberadaanya (Sobur, 2004:69).

\section{Tujuan Penelitian}

Penelitian yang dilakukan memiliki tujuan untuk melihat pemaknaan simbol-simbol iklan Sampoerna Hijau versi “Dateng Kondangan” dalam kajian semiotika.

\section{Kerangka Teori}

Dalam penelitian ini, peneliti menggunakan teori semiotika Roland Barthes. Metode Semiotik Roland Barthes berusaha menggali hakikat sistem tanda yang beranjak keluar kaidah tata bahasa dan sintaksis dan yang mengatur arti teks yang rumit, tersembunyi dan bergantung pada kebudayaan. Hal ini kemudian menimbulkan perhatian pada makna tambahan (connotative) dan arti penunjukkan (denotative) (Sobur, 2004: 126-127). 


\section{Gambar 1}

\section{Metode Roland Bhartes}

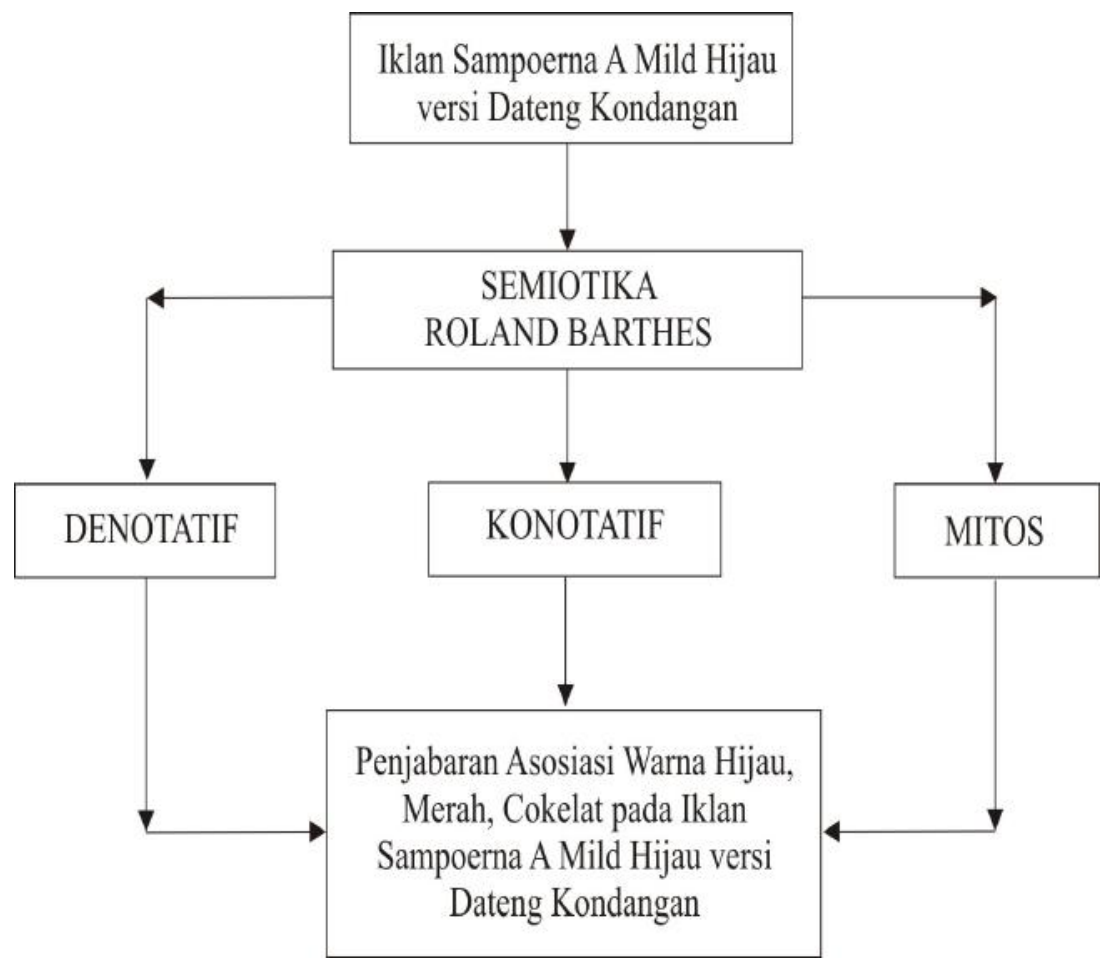

\section{Metode Penelitian}

Pendekatan yang digunakan dalam penelitian ini adalah pendekatan kualitatif yaitu pendekatan yang digunakan karena beberapa pertimbangan yang bersifat luwes, tidak lazim mengidentifikasikan suatu konsep serta memberi kemungkinan bagi perubahan-perunahan manakala ditemukan fakta yang lebih mendasar, menarik, dan unik di lapangan.(Bungin, 2003:9).Teknis analisis data dengan menggunakan semiotika model Roland Barthes seperti makna denotasi, makna konotasi, dan mitos yang digunakan untuk memahami makna yang terkandung dalam setiap scene iklan Sampoerna A Mild Hijau versi “Dateng Kondangan”. Barthes menyebutnya sebagai denotasi yaitu makna paling nyata dari tanda.Konotasi adalah istilah yang digunakan Barthes untuk menunjukan signifikasi tahap kedua, hal ini menggambarkan interaksi yang terjadi ketika tanda bertemu dengan perasaan atau emosi. Dengan kata lain denotasi adalah apa yang digambarkan tanda terhadap objek sedangkan konotasi adalah bagaimana menggambarkannya. Sedangkan mitos menurut Roland Barthes adalah keberadaan fisik tanda (denotasi) dan konsep mental (konotasi).menjelaskan beberapa aspek dari sebuah realitas.

\section{Hasil Penelitian dan Pembahasan}

Pada hal ini akan dilakukan pembahasan mengenai breakdown iklan Sampoerna Hijau Versi "DATENG KONDANGAN" (dari https://www.youtube.com/watch?v=K3dJp1D8r80) dengan mengambil beberapa adegan / scene yang akan dibahas dengan analisis semiotika Roland Barthes. 


\section{Gambar 2}

\section{Establishing Shoot Pemandangan / Suasana Kondangan}

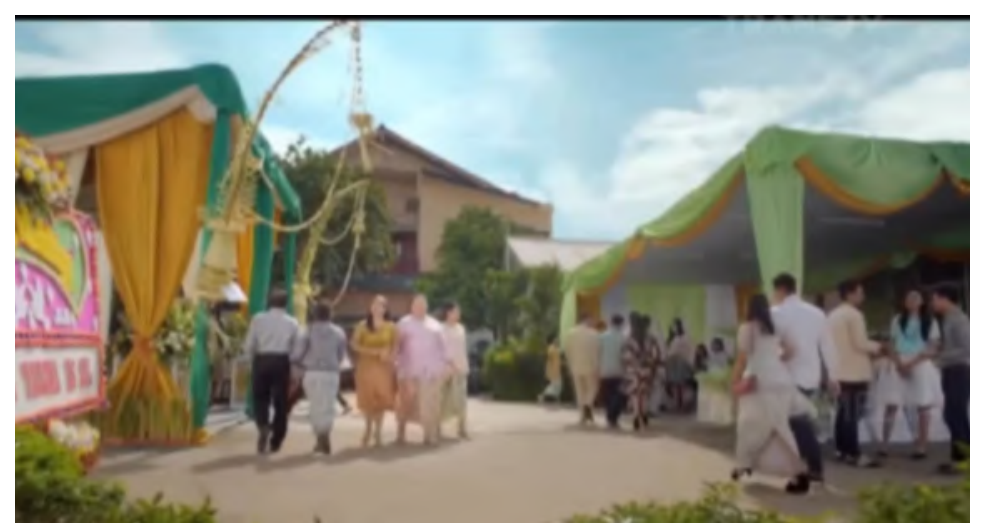

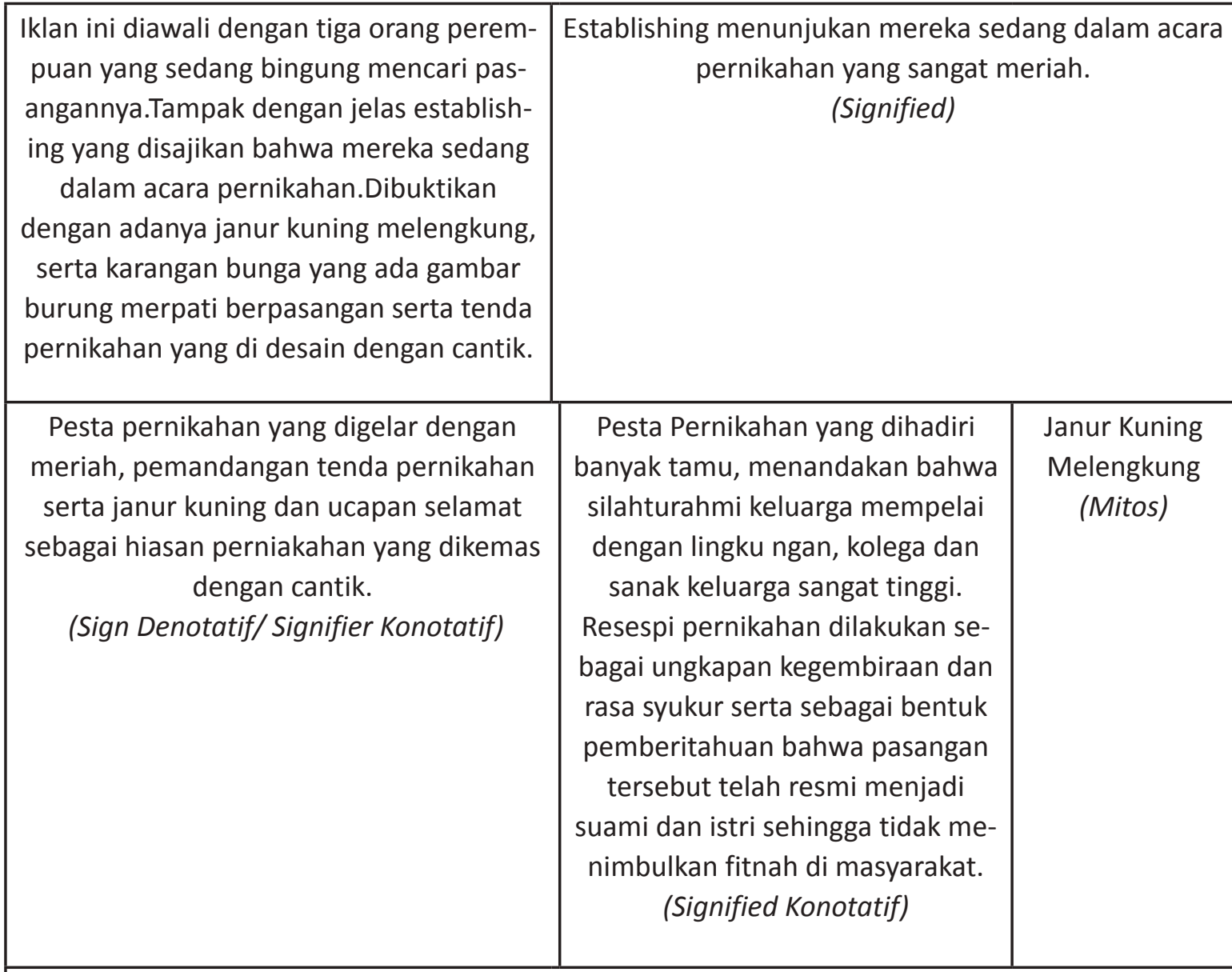

Pesta Pernikahan yang digelar sangat meriah dengan dihadiri oleh banyak tamu yang datang, menandakan ajang silahturahmi keluarga serta lingkungan sekitar untuk berbagi kebahagiaan

(Sign Konotatif)

\section{Keterangan :}

Makna Denotasi dari scene diatas adalah pesta / resepsi pernikahan yang digelar dengan meriah ditandai dengan tenda pernikahan serta janur kuning dan ucapan selamat sebagai hiasan perniakahan yang dikemas dengan cantik.Tampak dari para tamu yang hadir cukup banyak dan lalu lalang.Makna Konotasi yang terbentuk yaitu pesta pernikahan yang dihadiri banyak tamu, menandakan bahwa silahturahmi keluarga mempelai dengan lingkungan, kolega 
dan sanak keluarga sangat tinggi.Resespi pernikahan dilakukan sebagai ungkapan kegembiraan dan rasa syukur serta sebagai bentuk pemberitahuan bahwa pasangan tersebut telah resmi menjadi suami dan istri sehingga tidak menimbulkan fitnah di masyarakat.Acara resepsi pernikahan dapat juga dijadikan sarana untuk berkumpulnya keluarga besar dan mempererat tali silahturahmi.Mitos dalam scene tersebut ditandai dengan adanya Janur Kuning melengkung yang ada dalam acara pernikahan.Janur Kuning Janur mempunyai makna : sejane ning Nur, arah menggapai cahaya llahi, Kuning sabda jadi yang dihasilkan dari hati atau jiwa yang bening dan filosofinya suatu cita-cita yang mulia untuk menggapai cahaya Illahi dengan hati yang bening dan untuk mendapatkan keberkahan. Begitu dalam makna religi pada kata janur kuning, dimana pihak yang memiliki hajat pesta resepsi pernikahan disimbolkanharapannya untuk menggapai ridho Illahi dengan ketetapan Allah SWT melalui jasmani rohani yang bersih pada pelaksanaan hajatnya. Harapan yang baik pada acara yang baik itulah esensi sesungguhnya yang ada pada janur kuning (Setyaningsih, dalam Teknobuga Volume 2 No. 1 - Juni 2015).

\section{Gambar 3}

Ketiga Tokoh Tergoda Dengan Sajian Jamuan Resepsi

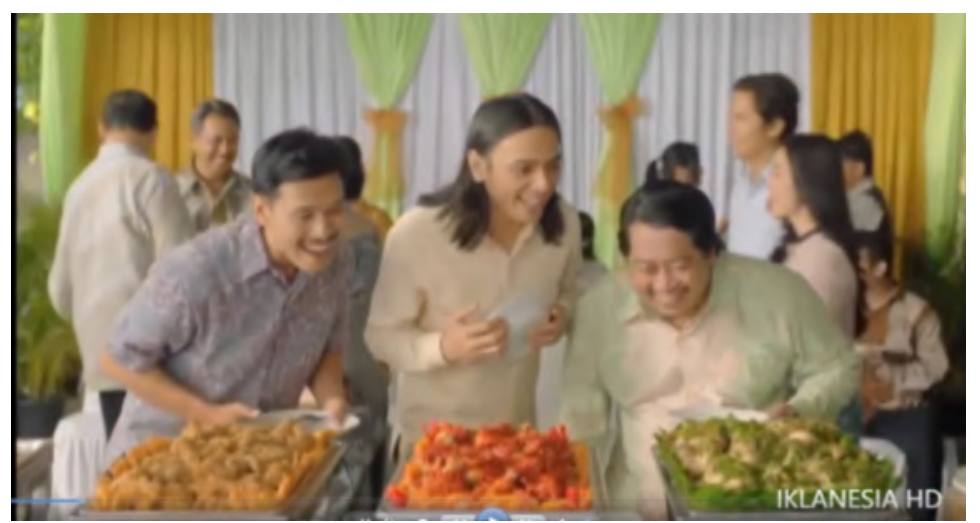

Iklan tersebut kemudian dilanjutkan dengan dengan tiga orang sahabat yang datang ke resepsi kondangan. Tampak dalam iklan tersebut mereka bertiga sangat tertarik dan tergoda untuk mencicipi sajian makanan yang ada pada acara tersebut. Gambar pembuka tersebut terdiri atas dua unsur yaitu audio dan visual. Unsur audio yaitu ada pada ucapan dari mereka, "Wah... menggoda nih..". Unsur visual yang tampak mewakili bahwa mereka sedang dalam acara pesta (background berupa tenda pernikahan)

\begin{tabular}{|c|c|}
\hline $\begin{array}{c}\text { Iklan ini diawali dengan tiga orang perempuan } \\
\text { yang sedang bingung mencari pasangannya. } \\
\text { Tampak dengan jelas establishing yang disajikan } \\
\text { bahwa mereka sedang dalam acara pernikahan. }\end{array}$ & $\begin{array}{c}\text { Tiga orang sahabat yang menghadiri resepsi } \\
\text { pernikahan dan tertarik dengan sajian makan- } \\
\text { an lezat. Dua dari tokoh tersebut lebih tergiur } \\
\text { dengan makanan yang berwarna hijau } \\
\text { Dibuktikan dengan adanya janur kuning meleng- } \\
\text { kung, serta karangan bunga yang ada gambar } \\
\text { burung merpati berpasangan serta tenda perni- } \\
\text { kahan yang di desain dengan cantik. } \\
\text { (Signifer) }\end{array}$ \\
\hline
\end{tabular}




\begin{tabular}{|c|c|}
\hline $\begin{array}{c}\text { Ramainya nuansa pernikahan yang meriah, dima- } \\
\text { na para tamu undangan begitu tertarik terhadap } \\
\text { sajian makanan dalam momen resepsi tersebut. } \\
\text { Dua dari tokoh utama dengan jelas lebih tertarik } \\
\text { dengan makanan yang berbumbu hijau. } \\
\text { (Sign Denotatif/Signifier Konotatif) }\end{array}$ & $\begin{array}{c}\text { Ramainya pangsa pasar rokok di Indonesia } \\
\text { dalam memenuhi permintaan konsumen. Dua } \\
\text { dari konsumen lebih tertarik dengan kemasan } \\
\text { awal pada produk rokok yang memiliki kema- } \\
\text { san hijau. }\end{array}$ \\
(Signified Konotatif)
\end{tabular}

\section{Keterangan :}

Makna Denotasi dari scene diatas adalah ramainya nuansa pernikahan yang meriah, dimana para tamu undangan begitu tertarik terhadap sajian makanan dalam momen resepsi tersebut. Sajian makanan yang tampak lezat di wakili dengan berbagai menu makanan yang bervariasi. Mulai dari makanan yang berbumbu merah, berbumbu coklat, hingga ada yang berbumbu hijau.Ketiga makanan tersebut begitu sangat menggiurkan. Namun dua dari tokoh tersebut dengan sangat jelas lebih tertarik dengan makanan yang berbumbu hijau.Makna Konotasinya adalah ramainya pangsa pasar rokok di Indonesia dalam memenuhi permintaan konsumen. Namun, Dua dari konsumen lebih tertarik dengan kemasan awal pada produk rokok yang memiliki kemasan hijau. Ketatnya persaingan pangsa pasar di Indonesia saat ini berhubungan dengan dominasi penjualan 3 brand rokok nasional yaitu Sampoerna (Hijau), Gudang Garam (Merah), dan Djarum (Coklat).

Peneliti mengambil kompetitor asosiasi warna merah adalah brand Gudang Garam dan asosiasi warna coklat adalah Djarum Coklat dikarenakan, Sampoerna Hijau melihat persaingan dari tiga sudut pandang yaitu harga, produk, dan segmen pasar (demografi dan psikografi). Menurut sisi pandang Sampoerna Hijau dari segi harga, dari tahun 2003, Sampoerna Hijau bandrolnya adalah Rp 5.000,-, maka pesaing terdekat adalah Gudang Garam Merah, Djarum 76 dan Djarum Coklat. Dari segi produk, Sampoerna Hijau tergolong sigaret kretek mesin, memiliki pesaing terdekat dari golongan rokok-rokok lintingan tangan. Dari segi segmentasi pasar yaitu kelas menengah yang aspirasional usia 25-35 tahun, maka pesaing terdekat adalah Djarum dan Gudang Garam. Dengan memperhitungkan ketiga sudut pandang tersebut maka pesaing terdekat yang berhadapan langsung dengan Sampoerna Hijau adalah Djarum dan Gudang Garam. (Diolah dari SWA terbitan 16-29 Oktober 2003, hal. mix 7 - dalam Hutabarat dan Jemsly : 2006 ) 


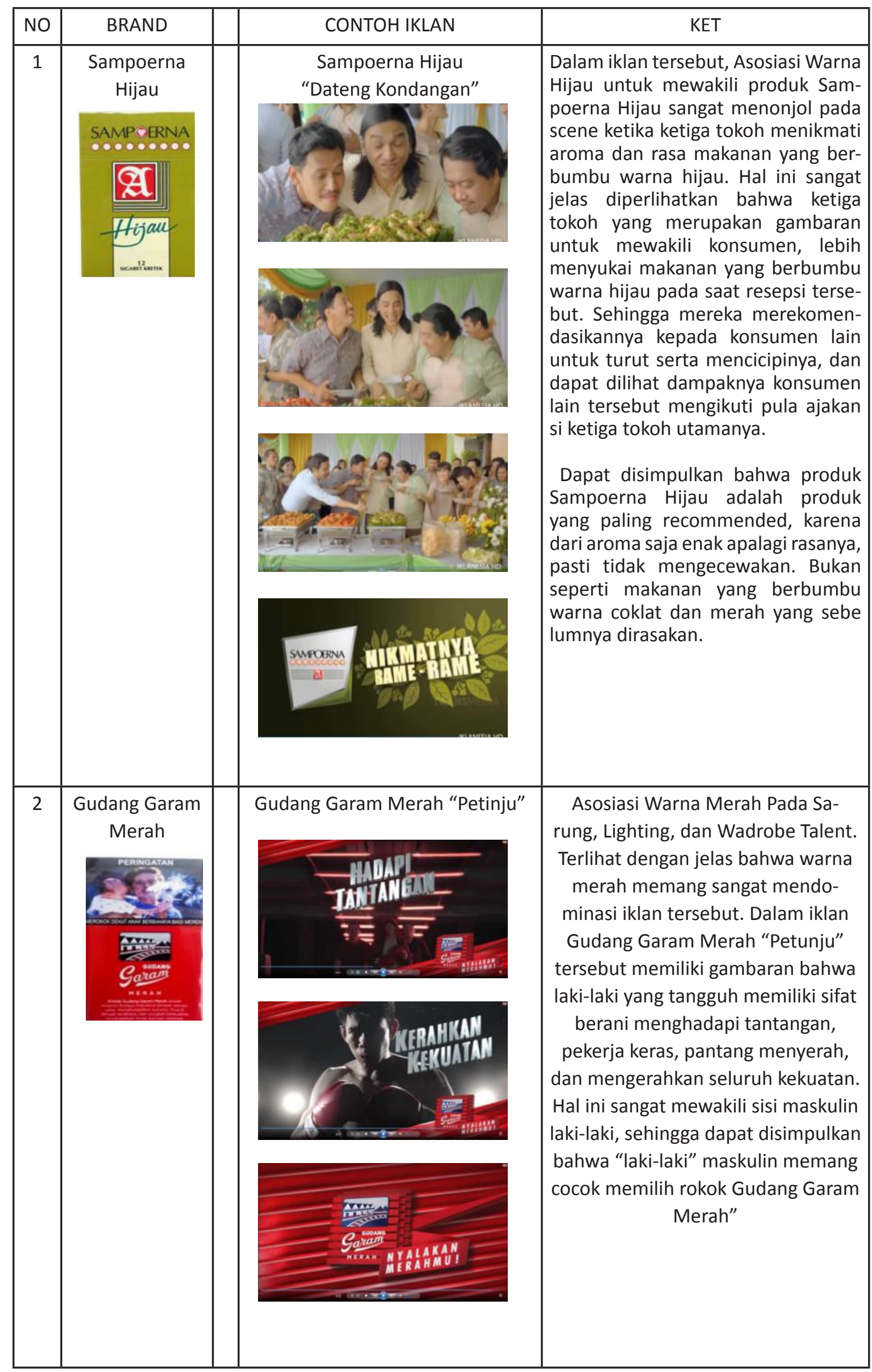




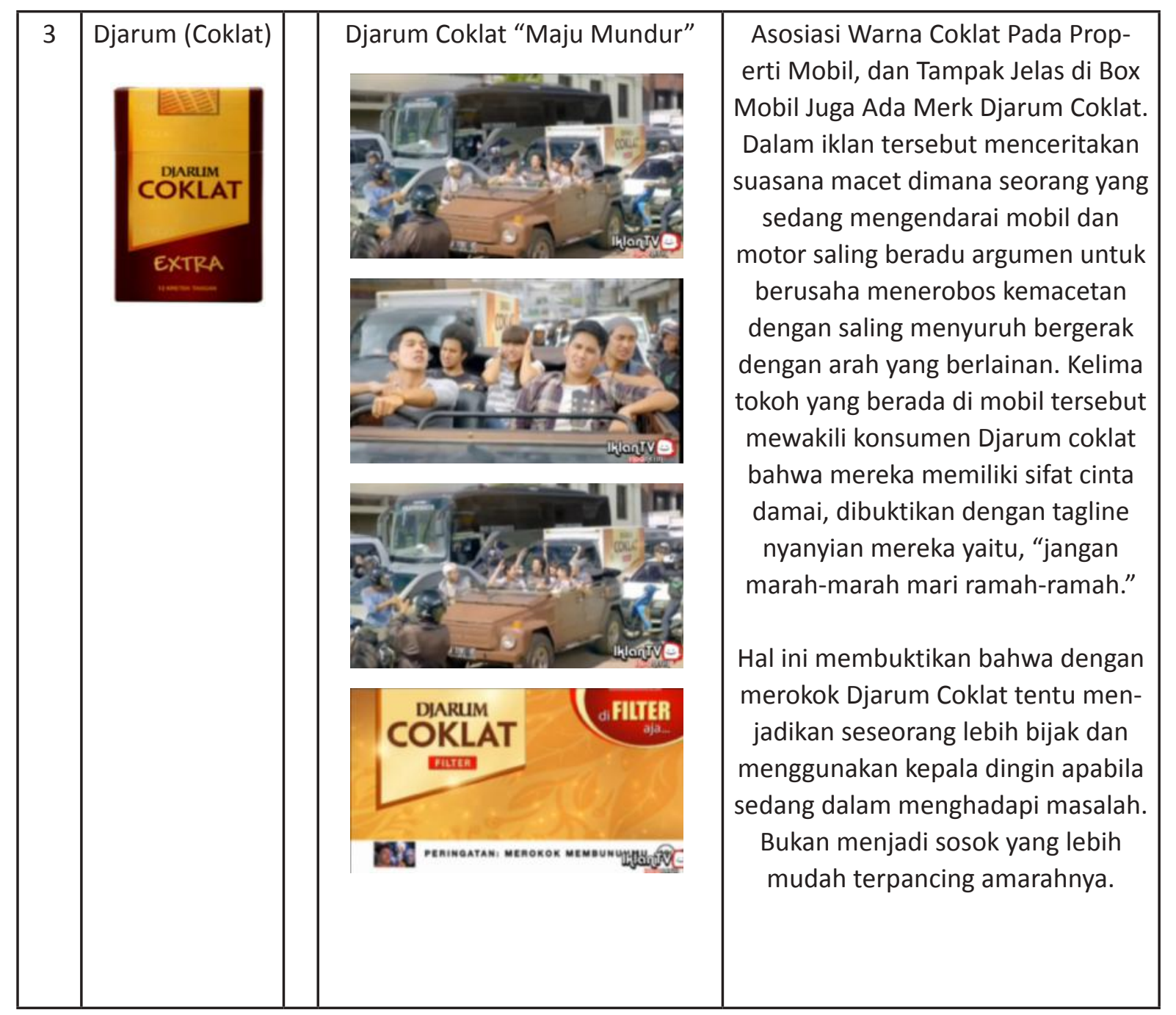

\section{Gambar 4}

Ketiga Tokoh Mencoba Makanan Berbumbu Warna Coklat

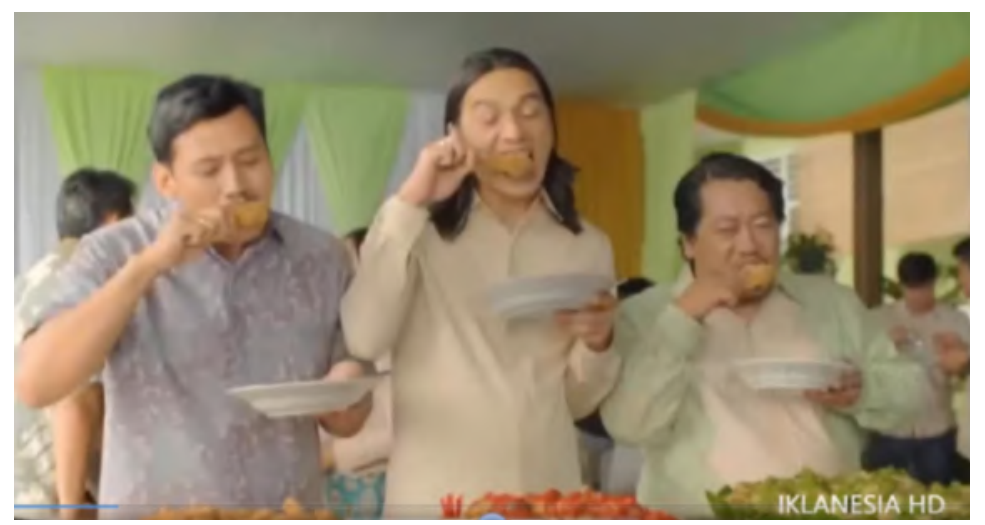

Dalam adegan selanjutnya ketiga orang sahabat tersebut mencoba terlebih dahulu satu-per satu sajian makanan dari acara resepsi tersebut.Makanan yang berwarna cokelatlah yang pertama kali mereka coba.Namun baru gigitan pertama, mereka kecewa dengan rasa dari makanan yang berwarna cokelat tersebut. Ada satu kalimat yang diucapkan, "Hambar.... " ,dilanjutkan dengan "He..eh.." oleh kawan lainnya. 


\begin{tabular}{|c|c|}
\hline & $\begin{array}{c}\text { Ketiga orang sahabat tersebut mencoba } \\
\text { terlebih dahulu satu-per satu sajian makanan } \\
\text { dari acara resepsi tersebut. Makanan yang } \\
\text { berwarna cokelatlah yang pertama kali mer- } \\
\text { eka coba } \\
\text { (Signified) }\end{array}$ \\
(Signifer) & $\begin{array}{c}\text { tSignified Konotatif) } \\
\text { (idak ada rasanya }\end{array}$ \\
$\begin{array}{c}\text { Ketiga sahabat tersebut mencoba makanan per- } \\
\text { tama yang disajikan dalam resepsi pernikahan. } \\
\text { pertama yang berwarna cokelat, karena rasanya } \\
\text { "hambar". (Sign Denotatif/Signifier Konotatif) }\end{array}$ & $\begin{array}{c}\text { menandakan bahwa produk rokok yang me- } \\
\text { miliki warna Brand Coklat rasanya tawar atal }\end{array}$ \\
\hline $\begin{array}{c}\text { Dalam scene ini Sampoerna ingin memberikan gambaran tersirat melalui Asosiasi warna cokelat } \\
\text { yang mewakili Brand Djarum (Coklat) memiliki kualitas cita rasa rokok yang hambar (mengecewakan } \\
\text { untuk dicoba). } \\
\text { (Sign Konotatif) }\end{array}$ \\
\hline
\end{tabular}

\section{Keterangan :}

Makna Denotasi pada scene tersebut memiliki gambaran bahwa makanan berwarna coklat yang disajikan pada acara resepsi tersebut tidak disukai oleh ketiga tokoh tersebut.Mereka kecewa dengan rasa dari makanan pertama yang berwarna cokelat, karena rasanya "hambar". Dalam gambaran tersebut rasa tidak enak bisa jadi dikarenakan bumbu yang ada pada makanan tersebut kurang sedap, sehingga hasil akhir yang dirasakan oleh tokoh tersebut menyatakan bahwa makanan tersebut tidak direkomendasikan untuk dinikmati ulang.Terbukti dengan scene selanjutnya, mereka langsung menikmati makanan yang berwarna bumbu merah. MaknaKonotasinya adalah bahwa iklan tersebut ingin menunjukkan bahwa Brand Djarum (Coklat) memiliki kualitas cita rasa yang tawar (tidak ada rasanya) sehingga diharapkan mampu mempengaruhi pilihan pembeli agar tidak memilih Brand Djarum (Coklat) untuk rokoknya. Dalam Kamus Besar Bahasa Indonesia (http://kbbi.web.id/hambar, diakses pada tanggal 20 Mei 2017), makna kata "hambar" adalah sesuatu yang yang tidak ada rasanya, tawar, atau hal yang tidak berasa.

\section{Gambar 5}

Ketiga Tokoh Mencoba Makanan Berbumbu Warna Merah

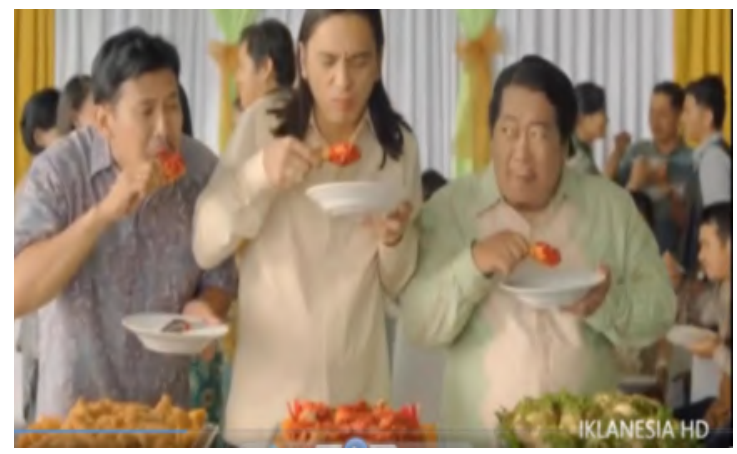


Dalam scene selanjutnya, ketiga tokoh yang awalnya mencoba makanan berwarna coklat kemudian melanjutkan untuk mencoba makanan yang berwarna merah.Mereka kecewa dengan makanan sebelumnya dan berharap bahwa makanan yang berwarna merah selanjutnya rasanya tidak hambar.Namun ternyata mereka juga kecewa setelah tahu rasa dari makanan yang berwarna merah, malahan rasanya tidak enak. Ada satu kalimat yang dengan jelas diucapkan oleh salah satu tokoh tersebut “... Gak Enak....”.

\begin{tabular}{|c|c|}
\hline (Signifer) & $\begin{array}{c}\text { Mereka melanjutkan untuk mencoba makanan } \\
\text { yang } \\
\text { berwarna merah. Mereka kecewa dengan } \\
\text { makanan } \\
\text { sebelumnya dan berharap bahwa makanan yang } \\
\text { berwarna merah rasanya tidak hambar } \\
\text { (Signified) }\end{array}$ \\
\hline $\begin{array}{l}\text { Setelah kecewa dengan makanan pertama yang } \\
\text { berwarna coklat, mereka mencoba } \\
\text { makanan yang berwarna merah. Namun ternyata } \\
\text { makanan merah malah memiliki rasa yang tidak } \\
\text { enak. (Sign Denotatif/ Signifier Konotatif) }\end{array}$ & $\begin{array}{c}\text { Menandakan bahwa produk rokok yang memiliki } \\
\text { Brand berwarna merah, memiliki rasa yang tidak } \\
\text { enak. } \\
\text { (Signified Konotatif) }\end{array}$ \\
\hline \multicolumn{2}{|c|}{$\begin{array}{l}\text { Dalam scene ini Sampoerna ingin memberikan gambaran tersirat melalui Asosiasi warna merah } \\
\text { yang mewakili Brand Gudang Garam Merah memiliki kualitas cita rasa rokok yang tidak enak (Sign } \\
\text { Konotatif) }\end{array}$} \\
\hline
\end{tabular}

\section{Keterangan :}

Makna Denotasi dalam scene ini adalah bahwa makanan yang berwarna merah rasanya tidak enak, bisa jadi dari segi bumbu kurang sedap sehingga menyebabkan ketiga tokoh tersebut ingin berpindah ke makanan yang selanjutnya.Mereka kecewa setelah tahu rasa dari makanan yang berwarna merah, malahan rasanya tidak enak. Ada satu kalimat yang dengan jelas diucapkan oleh salah satu tokoh tersebut "Gak Enak....".Kalimat tersebut tentu saja dengan sudah mewakili bahwa makanan yang berbumbu warna merah tidak direkomendasikan untuk dinikmati lagi.Makna Konotasi dari adegan tersebut menyimbolkan bahwa rokok yang memiliki Brand berwarna merah, memiliki rasa yang tidak enak.Brand rokok yang dimaksud adalah kompetitor dari Sampoerna, yaitu Gudang Garam Merah. Dengan demikian, Sampoerna ingin menggiring opini publik yang melihat tayangan iklan ini bahwa rokok yang memiliki asosiasi warna merah (Gudang Garam Merah), baik dari segi kemasan, properti, tagline, dan logo desain adalah produk rokok yang mempunyai rasa tidak enak, sehingga tidak direkomendasikan untuk dipilih. 


\section{Gambar 6}

\section{Ketiga Tokoh Lebih Memilih Makanan Berbumbu Warna Hijau}

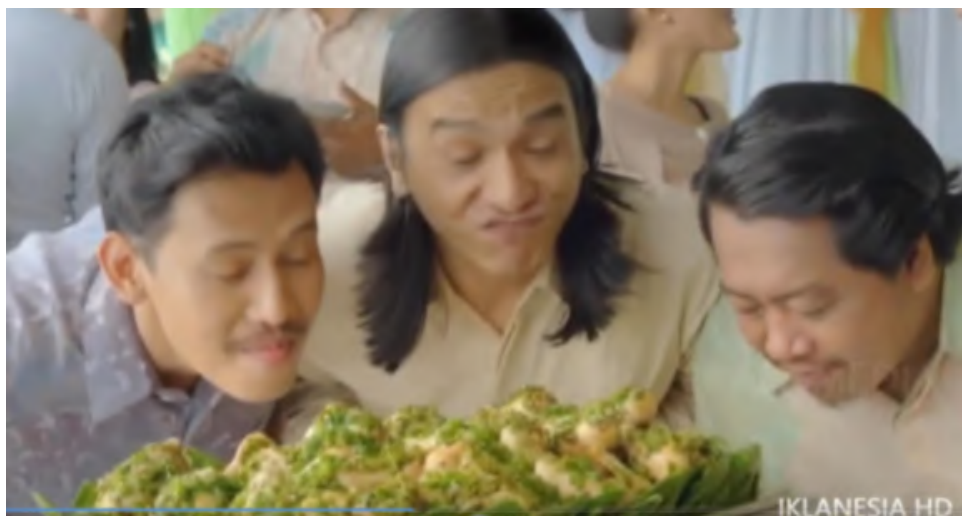

Adegan ini menunjukan bahwa makanan yang berwarna Hijau mampu menarik perhatian dari ketiga tokoh tersebut. Salah satu tokoh tersebut mengucapkan kalimat, "Aromanya saja.... Nikmat..!", yang memiliki arti bahwa dari aroma saja makanan tersebut enak, apalagi rasanya, pasti tambah enak, tidak mengecewakan seperti makanan pertama yang berwarna coklat dan makanan kedua yang berwarna merah.

\begin{tabular}{|c|c|}
\hline & $\begin{array}{c}\text { Mereka melanjutkan untuk mencoba makanan yang } \\
\text { berwarna hijau. Mereka sangat menyukainya, } \\
\text { karena dari aromanya saja nikmat, apalagi rasanya } \\
\text { pasti tambah nikmat / enak } \\
\text { (Signified) }\end{array}$ \\
\hline $\begin{array}{c}\text { Setelah kecewa dengan makanan yang ber- } \\
\text { warna coklat dan merah, mereka tertarik un- } \\
\text { tuk mencoba makanan yang berwarna hijau. } \\
\text { Karena dari } \\
\text { aromanya saja nikmat/enak, pasti rasanya } \\
\text { juga } \\
\text { nikmat/enak. (Sign Denotatif/Signifier Kono- } \\
\text { tatif) }\end{array}$ & $\begin{array}{l}\text { Menandakan bahwa produk rokok yang memiliki } \\
\text { Brand } \\
\text { berwarna Hijau memiliki aroma dan rasa yang nik- } \\
\text { mat dan enak } \\
\text { (Signified Konotatif) }\end{array}$ \\
\hline \multicolumn{2}{|c|}{$\begin{array}{l}\text { Dalam scene ini Sampoerna ingin memberikan gambaran tersirat melalui Asosiasi warna Hijau yang } \\
\text { mewakili Brand Sampoerna Hijau mempunyai kualitas cita rasa rokok yang enak, terbukti dari segi } \\
\text { aroma saja sudah nikmat apalagi rasanya pasti tambah nikmat.(Sign Konotatif) }\end{array}$} \\
\hline
\end{tabular}

\section{Keterangan :}

Makna denotasi dalam scene tersebut menandakan bahwa makanan yang berwarna hijau patut untuk dicoba, karena rasanya pasti tidak mengecewakan. Hal ini terbukti dari aromanya saja nikmat apalagi rasanya.Makanan yang dibumbui dengan bumbu berwarna Hijau tersebut sangat sedap sehingga menarik perhatian dari ketiga talent tersebut.Makna Konotasinya adalah bahwa produk rokok yang memiliki asosiasi warna hijau adalah rokok yang yang 
memiliki aroma dan cita rasa yang enak. Dengan kata lain bahwa adegan tersebut mewakili kualitas dan keunggulan dari produk rokok Sampoerna Hijau yang tidak akan mengecewakan para perokoknya. Scene ini kemudian didukung oleh adegan dari ketiga tokoh mengajak tamu undangan lain untuk ikut serta mencoba makanan yang berbumbu hijau. Dan ternyata tamu undangan lain pun dengan suka cita bersedia untuk mencoba pula makanan tersebut. Hal ini membuktikan bahwa faktor rasa dan aroma produk Sampoerna Hijau sangat unggul kualitasnya, sehingga para penikmat rokok tanpa pikir panjang langsung memilih produk Sampoerna Hijau yang sudah teruji cita rasanya.

\section{Gambar 7}

\section{Ketiga Tokoh Menyukai Makanan Berwarna Hijau dan Merekomendasikan Kepada Tamu Lainnya}

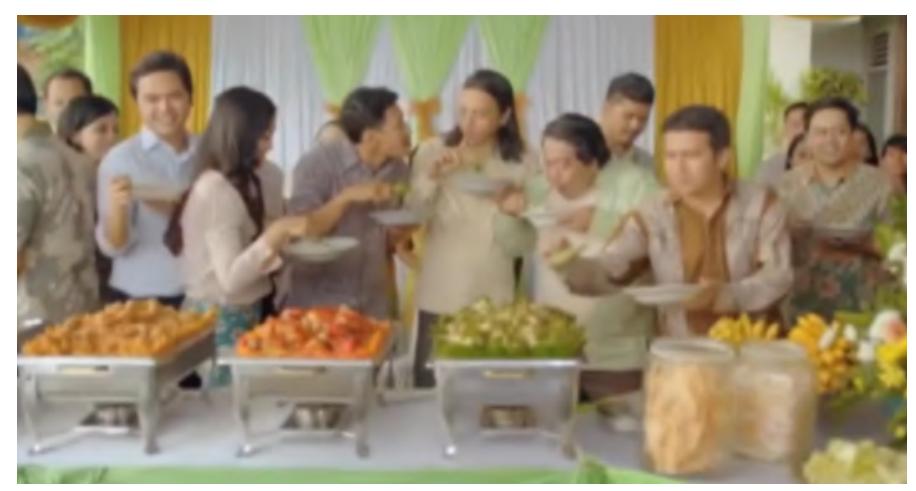

Adegan tersebut menceritakan bahwa para tamu yang datang ke acara resepsi tersebut ikut juga merasakan dan mencoba makanan warna Hijau yang enak.Banyak dari tamu tersebut tidak segan untuk langsung ikut mengambil dan mencicipinya.

\begin{tabular}{|c|c|}
\hline P & $\begin{array}{l}\text { Para tamu undangan yang lain juga ikut mencicipi } \\
\text { dari makanan yang berwarna Hijau karena rasanya } \\
\text { yang nikmat (Signified) }\end{array}$ \\
\hline (Signifer) & \\
\hline $\begin{array}{l}\text { Makanan yang berwarna Hijau dipilih oleh } \\
\text { banyak tamu undangan dalam acara resepsi } \\
\text { tersebut (Sign Denotatif/Signifier Konotatif) }\end{array}$ & $\begin{array}{l}\text { Menandakan bahwa produk rokok yang memiliki } \\
\text { Brand berwarna Hijau adalah pilihan banyak orang } \\
\text { (Signified Konotatif) }\end{array}$ \\
\hline \multicolumn{2}{|c|}{$\begin{array}{l}\text { Menampilkan bahwa Brand Rokok Sampoerna Hijau adalah produk yang paling banyak diminati } \\
\text { oleh masyarakat, dikarenakan kualitasnya yang unggul sehingga penikmat rokok tidak ragu untuk } \\
\text { mencobanya. } \\
\text { (Sign Konotatif) }\end{array}$} \\
\hline
\end{tabular}




\section{Keterangan :}

Makna Denotasi dari adegan tersebut adalah makanan yang berwarna bumbu Hijau adalah pilihan banyak tamu, hal ini mungkin dikarenakan dari segi bumbu yang diracik begitu lezat dan sedap sehingga para tamu tidak ragu untuk langsung mengambil dan mencicipinya.Makna Konotasinya adalah bahwa Brand Rokok yang memiliki asosiasi warna Hijau memiliki cita rasa yang tinggi, enak, dan nikmat sehingga menjadi pilihan utama serta yang banyak diminati oleh masyarakat.Selain itu, tagline iklan produk Sampoerna Hijau yaitu "Nikmatnya Rame-rame", menggambarkan bahwa salah satu cara terbaik untuk menikmati produk rokok tersebut adalah dengan dinikmati bersama-sama. Dalam arti bersama sahabat, teman sepergaulan atau yang lainnya. Hal ini tentu termasuk salah satu teknik promosi untuk meningkatkan penjualan.Karena semakin banyak orang yang bersedia untuk memilih produk Sampoerna Hijau ketika mereka berkumpul, semakin banyak pula produk Sampoerna Hijau yang mereka beli.

\section{Gambar 8}

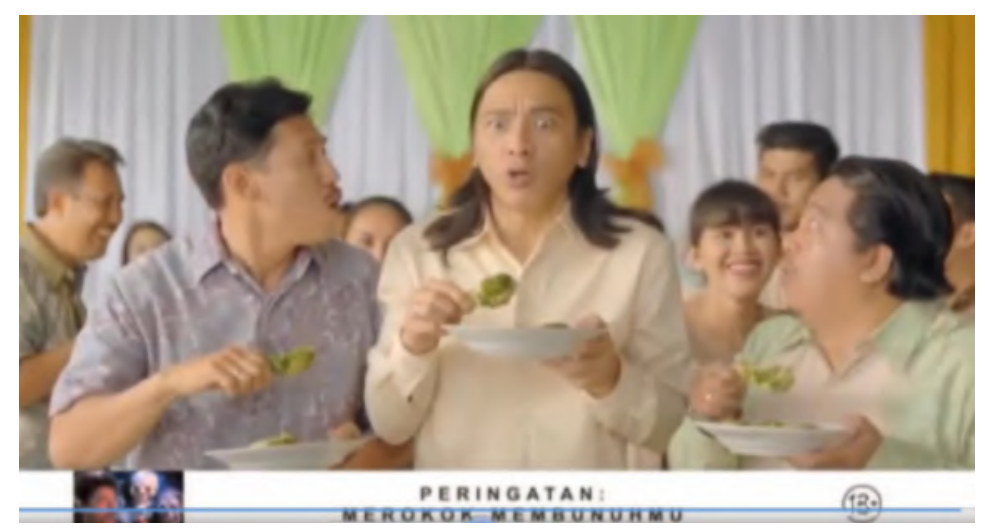

Iklan tersebut diakhiri dengan adegan adanya peringatan dari pasangan ketiga tokoh utama laki-laki.Peringatan tersebut berupa pemberitahuan bahwa ketiga tokoh laki-laki salah menghadiri tempat resepsi Undangan.

\begin{tabular}{|c|c|}
\hline & $\begin{array}{c}\text { Ketiga tokoh utama terkejut setelah menden- } \\
\text { gar peringatan bahwa mereka salah datang ke } \\
\text { tempat resepsi } \\
\text { (Signified) }\end{array}$ \\
\hline $\begin{array}{c}\text { Ketiga tokoh tersebut terkejut ternyata mereka } \\
\text { salah datang ke tempat resepsi pernihakan orang } \\
\text { lain. (Sign Denotatif/ Signifier Konotatif) }\end{array}$ & $\begin{array}{c}\text { Kenikmatan saat menghisap Sampoerna melu- } \\
\text { pakan pria pada rencananya } \\
\text { (Signified Konotatif) }\end{array}$ \\
\hline \multicolumn{2}{c}{ (Sign Konotatif) } \\
\hline
\end{tabular}




\section{Keterangan :}

Perusahaan Sampoerna dengan brand Sampoerna Hijau melalui scene diatas ingin membangun mitos lainnya, yaitu dengan hadirnya rasa nikmat produk Sampoerna Hijau yangmembuat orang lupa akan sesuatu. Seolah-olah produk ini merupakan sahabat yang paling dekat dan nikmat yang mengerti bagaimana konsumen mendapatkan kenikmatan saat menghisapnya. Apabila di analisis dari screenshoot scene dari awal hingga akhir digabungkan, terciptalah pesan tersirat bahwa Perusahaan Sampoerna secara serius dan bersungguh-sungguh menyediakan dan menyuplai produk berkualitas cita rasa tinggi kepada masyarakat Indonesia.PT Sampoerna Tbk. melalui salah satu produk unggulannya yakni Sampoerna Hijau telah berusaha menjadi yang terbaik, ternikmat, dan memiiliki differensiasi bagi para pesaingnya. Sampoerna Hijau menhadirkan produk yang kualitasnya bagus, sedap, nikmat, bahkan ketika konsumen baru mencium aromanya pun sudah terasa enaknya.

\section{Simpulan}

Dalam proses pencarian atau penemuan makna yang tersembunyi dibalik tanda-tanda pada iklan rokok Sampoerna Hijau versi "DATENG KONDANGAN" sangat membutuhkan proses yang panjang dan cukup rumit. Hal ini dikarenakan konsep iklan rokok tersebut terlalu kreatif, sehingga mendorong dan memicu penulis untuk berfikir lebih jauh serta lebih mendalam. Penggunaan teori semiotika Roland Barthes dalam mengungkap makna denotasi, konotasi serta mitos, dengan konsepnya lebih terstruktur cukup sesuai dengan karakteristik dan konsep dari iklan yang banyak mengandung makna tersembunyi baik melalui teks, audio, maupun unsur visualnya. Hasil temuan dan analisis penulis dalam penelitian ini adalah bahwa Perusahaan Sampoerna secara serius dan bersungguh-sungguh menyediakan dan menyuplai produk berkualitas cita rasa tinggi kepada masyarakat Indonesia.PT Sampoerna Tbk. melalui salah satu produk unggulannya yakni Sampoerna Hijau telah berusaha menjadi yang terbaik, ternikmat, dan memiiliki differensiasi bagi para pesaingnya terlebih melalui konsep iklannya. Adapun penjabarannya adalah sebagai berikut :

a. Makna Denotasi

Creator iklan rokok Sampoerna Hijau versi "DATENG KONDANGAN" mencoba membuat iklan dengan konsep ketiga sahabat yang datang ke acara respesi pernikahan dan mereka sangat antusias dengan sajian makanan yang ada pada perhelatan acara tersebut.Dimulai dengan mencoba makanan yang berbumbu warna merah, coklat, hingga mencoba yang warna hijau.Dari ketiga makanan tersebut, makanan yang berwarna bumbu hijaulah yang sangat diminati dan direkomendasikan kepada banyak tamu lainnya yang hadir, dikarenakan makanan yang berbumbu hijau tersebut dari aromanya saja enak, apalagi dari segi rasa pasti lebih nikmat.

b. Makna Konotasi

Makna konotasi dalam iklan Sampoerna Hijau versi "DATENG KONDANGAN" adalah bentuk penggambaran persaingan produk rokok di Indonesia yang diwakili oleh brand kompetitor dimana asosiasi warna merah mewakili brand rokok Gudang Garam Merah, sedangkan 
warna coklat mewakili brand rokok Djarum Coklat.Warna Hijau sendiri jelas mewakili brand rokok Sampoerna Hijau. Dalam iklan tersebut, ketiga sahabat dan rekan tamu undangan yang lain mewakili gambaran konsumen rokok di Indonesia. Ternyata diakhir cerita iklan tersebut, mereka semua lebih tertarik dan menyukai makanan yang berbumbu warna Hijau, dimana asosiasi warna hijau adalah brand rokok Sampoerna Hijau. Sehingga dapat disimpulkan bahwa rokok Sampoerna Hijau adalah brand rokok yang sangat enak dan sangat recommended untuk dinikmati dibanding dengan merk kompetitor lainnya.

c. Mitos

Dalam iklan tersebut penulis hanya menemukan satu mitos saja dalam ceritanya.Yaitu adanya janur kuning melengkung yang ada di acara pernikahan. Janur Kuning Janur mempunyai makna bahwa sejane ning Nur, arah menggapai cahaya llahi, Kuning sabda jadi yang dihasilkan dari hati atau jiwa yang bening dan filosofinya suatu cita-cita yang mulia untuk menggapai cahaya Illahi dengan hati yang bening dan untuk mendapatkan keberkahan. Begitu dalam makna religi pada kata janur kuning, dimana pihak yang memiliki hajat pesta resepsi pernikahan disimbolkan harapannya untuk menggapai ridho Illahi dengan ketetapan Allah SWT melalui jasmani rohani yang bersih pada pelaksanaan hajatnya. Harapan yang baik pada acara yang baik itulah esensi sesungguhnya yang ada pada janur kuning.

\section{Daftar Pustaka}

Bungin, Burhan. (2003). Analisis Data Penelitian Kualitatif. Jakarta: PT Raja Grafindo Persada. Kartajaya, H., dkk. (2005). Positioning, Diferensiasi, dan Brand. Jakarta: Gramedia Hidayat, Taufik. (2005). Benah-benah Sampoerna Hijau : Agar Hijau Semakin Hijau. Diolah dari majalah SWA edisi 14/2005, 7 Juli 2005, diakses pada tanggal 1 Mei 2017

Lee, Monle dan Johnson Carla. (2004). Prinsip-Prinsip Pokok Periklanan Dalam Perspektif Global. Jakarta: Prenada Media.

Hutabarat, Jemsley dan Martani Huseini. (2006). Opersionalisasi Strategi. Persaingan Sigaret Kretek. Jakarta : Elek Media Komputindo.

Setyaningsih, Endang. (2015). Tarub Dan Perlengkapannya Sarat Dengan Makna dan Filosofi dalam Teknobuga, Volume 2 No. 1 - Juni 2015, Diakses pada 20 April 2017, 20.00 WIB

Sobur,Alex. (2004). Semiotika Komuniksi. Bandung : PT Remaja Rosdakarya.

Komisi Penyiaran Indonesia. (2012). Pedoman Perilaku Penyiaran dan Standar Program Siaran (P3SPS) Pasal 59 ayat 2. Jakarta

Peraturan Pemerintah Republik Indonesia No.19 tahun 2003 tentang Pengamanan Rokok Bagi Kesehatan pasal 16 ayat 3

Iklan Sampoerna Hijau Versi "DATENG KONDANGAN" (dari https://www.youtube.com/ watch?v=K3dJp1D8r80, Diakses pada17 Maret 2017, 11.30 WIB) 